народжених 3 нервово-психічними розладами, покращенню показників фізіологічного та психічного здоров'я нації в цілому.

\title{
Література:
}

1. Астахов В. М., Пузь І. В. Пренатальна і перенатальна психологія як складові частини психології розвитку. Проблема девіантного материнства: стан і шляхи вирішення. Медичні аспекти здоров'я жінки. 2011. № 1. С. 41-45.

2. Добряков I. В. Перинатальная психология - новий раздел клинической (медицинской) психологии. Електронний науковий журнал. 2012. № 5. URL: http://medpsy.ru/mprj/archiv_global/2012_5_16/ nomer/nomer27.php (дата звернення: 23.09.2020)

3. Добряков І. В. Перинатальна психологія. Пітер, 2010. 234 с.

4. Слободяник О. Я. Использование «Партнерских родов» для снижения акушерской патологии. Збірник наукових праџь інституту психологї імені Г. С. Костюка НАПН України. Психологічні науки. Київ, 2012. Том 5. Випуск 12. С. 162-168.

DOI https://doi.org/10.30525/978-9934-588-80-8-1.9

\section{ОСОБЛИВОСТІ ФОРМУВАННЯ ОСОБИСТОСТІ ВИПУСКНИКА ЕЛІТНОГО ТА ФАХОВОГО УНІВЕРСИТЕТУ}

\author{
Зеленько О. А. \\ кандидат медичних наук, \\ дочент кафедри загальної психологї \\ Київський національний університет імені Тараса Шевченка \\ м. Київ, Україна
}

Метою роботи є представлення погляду на формування особистості випускника елітного університету у порівнянні 3 особистістю випускника профільного фахового університету. Сучасна епоха характеризується переходом від доби технологічної революції до доби інформації. 3 другої половини XIX століття до кінця XX століття найбільш затребуваним продуктом системи вищої освіти був високо інформований та озброєний навичками фахівець. Університетська освіта полягала в першу чергу в тому, аби дати максимальну кількість знань та навчити користуватися ними для швидкого та ефективного вирішення задач, які ставилися перед фахівцем виробництвом та 
суспільством. 3 розширенням інформаційних систем та вільним доступом до гігантських масивів інформації змінилися не лише умови функціонування фахівця, а й постала потреба відокремити власне висококваліфікованого фахівця від фахівця, здатного діяти на державному та міжнародному рівнях, тобто фахівця-елітника.

Університет, який має готувати фахівця-спеціаліста, повинен будувати свою діяльність згідно того кінцевого продукту, який має надавати суспільству. Це - галузевий фаховий університет. Його діяльність має бути представлена двома основними напрямками: виховання, тобто формування особистості, та освіти як процесу отримання знань та навичок цими знаннями оперувати. Головним в цій діаді є перший компонент - формування особистості. Особистість, яку формує галузевий університет, повинна вміти оперувати необхідними знаннями та в умовах недостатності цих знань 3 метою отримання конкретного кінцевого результату, який фактично $\epsilon$ единим/ найкращим/найефективнішим варіантом розв'язання конкретної задачі чи проблеми. Це рішення, яке можна називати правильнім, $\epsilon$ детерміновано конкретним проміжком часу, конкретними обставинами та конкретними вимогами. За умов зміни будь-якого 3 цих обставин отримане фахівцем правильне рішення може стати будь-яким на лінійці від недостатньо ефективного до катастрофічно помилкового. Особистість, яка функціонує в таких умовах, повинна вміти швидко трансформуватися у відповідності до поставлених завдань та узгоджувати свої дії та рішення з тим результатом, який очікує від його діяльності суспільство та роботодавець - хоч держава, хоч приватна структура. Образно кажучи, фахівець повинен вміти в будь-яких умовах розв'язати поставити задачу таким чином, аби 1) відповідь була правильною - очікуваною або такою, яку вимагають, та 2) алгоритм розв'язання повинен бути зрозумілим, відтворюваним та обгрунтованим. Отже, діяльність особистості фахівця спрямована на пошук єдиного правильного в конкретних умовах результату із застосуванням правильного в даних умовах алгоритму діяльності. Таким чином, можна вважати, що особистість фахівця має функціонувати інваріантно: є один варіант правильний, а всі інші неправильні. Таке функціонування вимагає особливого характеру формування особистості, який направлений на такі моменти:

1) вміння врівноважено емоційно та когнітивно функціонувати в умовах дефіциту необхідних знань та навичок:

2) вміння знаходити необхідні знання та навички швидко та цілеспрямовано, вміючи відокремлювати необхідне «тут та зараз» від корисного взагалі, але не в конкретних умовах; 
3) мати високу здатність командної діяльності та високі комунікативні здатності та навички, адже це дає можливість більш ефективно вирішувати поставлені конкретні завдання;

4) чітко та впевнено усвідомлювати критерії ефективності функціонування індивідуумів, груп та систем.

Оптимальним для вирішення таких задач є компетентнісний метод навчання.

Зовсім інші завдання стоять перед випускником елітного університету. Разом з глибоким володінням великою кількістю знань та навичок, необхідних для діяльності безпосередньо всередині однієї конкретної галузі чи на межі споріднених галузей, випускник елітного університету має вирішувати проблеми, які мають щонайменше кілька варіантів правильних рішень, кожен з яких розгортає альтернативний варіант розвитку великих соціальних груп (корпорацій, галузей економіки, державних установ та інституцій, держав в цілому та міждержавних стосунків). Згідно 3 психологічним підходом до вирішення цієї проблеми з ним еліта і маса наділені особливими, лише їм властивими психологічними якостями. Серед психологічних тлумачень еліт поширеною $є$ концепція 3. Фройда, який вважав, що диференціація суспільства на еліту i масу виникла 3 родового авторитету. Людській масі та окремій людині властива потреба в авторитетові як втіленню батьківської опіки, що існувала в дитинстві. У дорослої людини це існує у сфері підсвідомого та виявляється в потребі підкорятися встановленим владою нормам і правилам. Зовнішні протиріччя - це вияв внутрішніх. I в кожної людини, за 3. Фройдом, є два начала - бажання життя (ерос) та бажання смерті (танатос). В еліти переважає перше, а в маси - друге. Масу 3. Фройд розглядав як вияв агресії первісної орди, тому насилля, що чинить еліта, $є$ благом для маси. На думку неофрейдистів (Е. Фромм та інші), протиріччя в існуванні еліти й маси зумовлені садистськомазохістськими механізмами. Характерні для елітарної орієнтації садистські тенденції означають бажання зробити інших залежними від своєї волі; прагнення використати особу для своїх цілей; потяг до фізичного, морального насилля. Масі властивий мазохізм, який, за Е. Фроммом, є одним із захисних механізмів, що допомагають людині запобігти ізоляції. Вона втікає від свободи, відповідальності за самостійні рішення і підкоряється встановленим владною елітою принципам. Звідси висновок: розмежоване існування еліти i мас психологічно зумовлене й політичне необхідне.

Щодо задач, які стоять у сфері формування особливості особистості випускника елітного університету, то вони полягають у такому: 40 
1) здатність бачити та усвідомлювати зв'язки між даними, явищами, об'єктами;

2) вміти мислити прогностично, розрізняючи коротко-, середньо- та довготривалу перспективу та наслідки прийнятого рішення;

3) усвідомлювати власну особистість та іiі потреби не лише на побутовому рівні (винагорода, житло, статус, пільги тощо), а у комплексі 3 інтересами існування та розвитку нації, держави, соціальної групи;

4) бажати та вміти брати на себе особисту відповідальність за прийняті рішення, грунтуючись не на зовнішніх вимогах та внутрішніх потребах, а насамперед на усвідомленні перспектив розвитку суспільства чи держави.

Досягнення такого рівня розвитку особистості випускника елітного університету неможливе за умов застосування лише компетентнісного підходу. Необхідно впровадження цілісного систематизованого класичного загальноосвітнього блоку знань протягом всього терміну навчання поряд зі значно більшим за обсягом у порівнянні з фаховим університетом масивом фундаментальних теоретичних знань та залучення майбутніх елітників ще під час навчання в університеті до участі у реалізації крупних проектів.

Не менш важливою умовою $є$ психологічний відбір кандидатів для навчання у цьому університеті з метою визначення рівня психологічної здатності кандидата до вирішення психолого-соціальних задач, які у майбутньому постануть перед ним.

\section{Література:}

1. Добряков А.А., Манушин Э.А. Модели инновационного ментально-структурированного учебного процесса. - Казань: Изд-во «Данис» ИПП ПО РАО, 2013, 265 с.

2. Добряков А.А. Психолого-педагогические основы подготовки элитных специалистов как творческих личностей. - М.: ЛОГОС, 2001, $311 \mathrm{c}$.

3. Добряков А.А. Концептуальная модель элитного специалиста XXI века и информационное пространство её реализации: Методическое руководство для преподавателей. - М.: Исследовательский центр проблем качества подготовки специалистов, 1998, 124 с.

4. Зеленько О.А. Психолого-педагогічне обгрунтування модернізації освітньої системи сучасної України. / Актуальні проблеми психології: Збірник наукових праць Інституту психології імені Г. С. Костюка НАПН України. - Том IX: Загальна психологія. Історична психологія. Етнічна психологія. - Випуск 10. С. 79-92. 
5. Зеленько О.А. Психологічне обгрунтування трансформації вищої школи України. / Науковий вісник НУБіП України. - Серія «Педагогіка, психологія, філософія». - № 239. - Київ, 2016. - С. 84-94.

6. Зеленько О.А. Регіональний гуманітарний (елітний) університет / Наукові записки НДУ ім. М. Гоголя, Психолого-педагогічні науки, випуск 2, Ніжин, 2020, С. 139-145.

7. Маслоу А. Мотивация и личность. К.: PSYLIB, 2004, 256 с.

8. Фрейд 3. Будущность одной иллюзии // Сумерки богов. М.: Политиздат, 1990, 398 с.

9. Фромм Э. Анатомия человеческой разрушительности. М.: ЭКСМО, 2017, $736 \mathrm{c.}$

10. Фромм Э. Бегство от свободы. М.: Академкнига, 2017, 288 с.

DOI https://doi.org/10.30525/978-9934-588-80-8-1.10

\title{
САМОТНІСТЬ ОСОБИСТОСТІ ЯК ПСИХОЛОГІЧНА ПРОБЛЕМА
}

\author{
Іваненко Б. Б. \\ кандидат психологічних наук, \\ дочент кафедри загальної психології \\ Київський національний університет імені Тараса Шевченка \\ м. Київ, Украӥна
}

Метою роботи є розгляд психологічних чинників, які призводять до небажаного почуття (стану) самотності дорослої особистості.

У сучасному суспільстві, незважаючи на тенденції індивідуалізації, розуміння «самотньої людини» пов'язанє із стереотипним сприйманням, міфами, упередженим ставленням. Свідомий вибір дорослої людини на користь самотнього життя нерідко розцінюється оточуючими як вимушений стан, що викликає страждання. Так, депресивні розлади, самодеструктивну поведінку, всякого роду залежності, на які стражає людина, намагаються пояснити іiї станом самотності. Інший стереотип - підтримка враження, що як тільки людина знайде партнера, здійснить вихід із самотнього життя, іiі психологічний стан покращиться, вона стане щасливою. Проте практика психологічної роботи доводить: схильність переживати почуття самотності глибоко вкорінена 3 дитинства, витоки самотнього стану всупереч бажанням людини - в психотравмах дитинства, які спричиняють страх емоційної 